\title{
Title: The Regional Battleground: Partisanship as a Key Driver of the Subnational Contestation of Citizenship
}

\author{
Author: Lorenzo Piccoli \\ University of Neuchâtel, Neuchâtel, Switzerland, and Robert Schuman Centre for Advanced Studies, \\ European University Institute, Florence, Italy \\ Rue Abram-Louis-Breguet 2, 2000, Neuchâtel Switzerland \\ Lorenzo Piccoli, lorenzo.piccoli@unine.ch, 0000-0002-4032-4793, +39 3485588652, \\ @piccolimeister
}

Acknowledgments: If there is any virtue to this article, the credit goes to Jean-Thomas Arrighi and Rainer Bauböck who commented extensively on it. I am also grateful to Camilla Alberti, Denise Efionayi-Mäder, Annique Lombard, Sean Mueller, Sarah Spencer, Dejan Stjepanovic and Verena Wisthaler, because they provided several useful suggestions on how to polish the main argument.

Declaration of conflicting interest: No potential conflict of interest was reported by the author.

Funding statement: This research was supported by the National Center of Competence in Research (NCCR) on the move funded by the Swiss National Science Foundation.

\begin{abstract}
This article challenges the idea that territorial rescaling invariably leads to a race to the bottom in the provision of rights for vulnerable subjects. Instead, the comparison of two regions in Italy and two cantons in Switzerland shows that subnational governments make different choices reflecting the preferences of their voters. While focusing on the case of undocumented immigrants and their inclusion/exclusion from health care, the article explains how subnational governments have appropriated certain categories of rights that constituted the hallmark of national citizenship for most of the twentieth century.
\end{abstract}

Keywords: Citizenship, territorial rescaling, undocumented migrants. 


\section{The Regional Battleground: Partisanship as a Key Driver of the Subnational Contestation of Citizenship}

\section{Introduction}

There is a strong tradition of research that treats the nation-state as the natural container of citizenship. Indeed, many scholars of the twentieth century, from Thomas H. Marshall (1950) to Rogers W. Brubaker (1992), have reinforced the idea that citizenship status and related rights depend upon decisions of territorially homogeneous nation-states. Yet, within most European states, decisions that were previously part of rigidly defined hierarchical structures have been steadily migrating to new levels of government over the course of the last forty years (Bartolini, 2005; Ferrera, 2005; Brenner, 2009). These processes of territorial rescaling enabled subnational actors to acquire significant room to manoeuvre over the definition of social and political rights (Keating, 1998, 2013; Hooghe, Marks and Schakel, 2010). Building upon this field of research, the present article asks whether and how the decentralisation of states affects rights that were traditionally used to define the boundaries of national citizenship, which is here understood as a status of membership linked to a bundle of rights in a self-governing political community.

More specifically, the article addresses the following questions: Do regional governments in multilevel states affect the citizenship status and citizenship rights of vulnerable populations? If so, how do they determine the scope and the scale of rights within multilevel states? And according to what drivers?

I divide this article into four sections in order to answer these questions. In the first section, I introduce the politics of regional citizenship by surveying a range of empirical examples and the literature on territorial rescaling. I draw two hypotheses from this: first, that the decentralisation of competences within multilevel states leaves room for regions to be involved in the making of citizenship rights; and, second, that due to the structural factors affecting decentralisation, this process will lead to a race to the bottom in the protection of vulnerable populations, as regions have structural constraints that force them to cut their social standards. In the section on research design, 
I justify the choice of the two countries (Italy and Switzerland), the specific domain of rights (health care) and the group of vulnerable individuals (undocumented immigrants) that I chose for my comparative analysis. In the results section, I show how regional governments shape the meaning of citizenship and I explain that the ideological orientation of governments at the regional level drives subnational variation in terms of the decisions regarding rights for undocumented individuals. In the conclusion, I wrap up my main argument: far from illustrating a defeat of politics before overwhelming structural changes that leave no room for agency, processes of territorial rescaling enable regional governments to steer the wheel of rights in one direction or the other, depending on their ideology and the voters they represent.

\section{The politics of regional citizenship}

While the determination of the status of citizenship that is 'not just rhetorical and metaphorical' remains an exclusive prerogative of central governments in virtually all European states (Joppke, 2010, p. 3), several rights that were traditionally used to define the boundaries of national citizenship are nowadays affected by municipal, regional, and supra-national governments. In his work on multilevel citizenship (2013), Willem Maas argues that a large number of citizenship statuses and rights in the twenty-first century are the product of ongoing interactions between states and other political institutions. Regional governments, in particular, have an important role in this process. It is possible, for instance, to imagine that a national government might want to extend certain social rights for all residents, while a regional government may be in favour of restricting them; conversely, a national government might lean towards the restriction of certain social rights as a way of controlling borders more effectively, while a regional authority may be keen to promote greater inclusion into them. The point is that the rights of individuals who are subject to multiple levels of government should be studied in terms of multiple levels of citizenship. The topic speaks directly to the contentious role of citizenship in the allocation of rights: this is what I shall refer to as the politics of regional citizenship. 
Outside Europe, the politics of regional citizenship is a core component of US federalism, due to the constitutional division of power enshrined in the American constitution. The balance between the equality of common federal citizenship and the diversity of subnational polities has enabled the existence of 'tiered, nested citizenships' (Schönberger, 2007, p. 61). This tradition goes back to the beginning of the republic: a common citizenship supplanted earlier state memberships only with the Fourteenth Amendment approved after the Civil War in 1868. Federalism in the US evolved without a clear direction as to whether citizenship rights are more likely to be expanded at the national or the subnational level. Southern states, for instance, used the politics of regional citizenship as a conservative tool to justify unequal treatment of black minorities and to resist federal attempts to address the legacies of slavery and segregation. By contrast, states also used the politics of regional citizenship to extend the pool of beneficiaries of certain rights: Wyoming, for instance, was the first government in the world to guarantee women the right to vote in 1869 (Greer, 2005, p. 4). Still today, the meaning of citizenship changes significantly across the US, because states remain the providers of some important entitlements, including the right to vote in state elections, to drive a vehicle, and to study at school.

Similar arguments have been advanced also with respect to multilevel countries outside the Western hemisphere. Two examples are India's multilevel polity and the states' responses to social policy (Deshpande, Kailash and Tillin, 2017) and Ethiopia's regional-states practices of enfranchisement and disenfranchisement (Ayele \& Visser, 2017). Here, too, the governments of subnational entities condition how social and political rights are shaped across the different provinces and territories.

Surprisingly, the question of how citizenship rights and statuses are politicised within multilevel states has hardly been studied in Europe. This is all the more startling in the light of the salience that regional citizenship has taken in the context of territorial contestation of European countries like the UK and Spain. During the campaign that led to the 2014 Scottish referendum on independence, for instance, social rights played a central role. The parties campaigning for 
independence defended the idea that Scotland must secede from the rest of the UK to protect its more progressive nation from social policy retrenchment pursued by the central government (Béland and Lecours, 2016); similarly, the constitutional crisis that followed the Catalan referendum of 1 October 2017 was portrayed by the Catalan government as a fight to uphold basic rights (see Arrighi, 2019). In fact, scholars studying the politics of regional citizenship in Europe have focused on regions with a special status of autonomy, where the issue of immigrant integration usually intersects with that of minority protection in general (Hepburn, 2011; Arrighi, 2012; Jeram, 2013; Jeram, van der Zwet and Wisthaler, 2015). These studies have connected the politicisation of regional rights and subnational territoriality to an internal quest for decentralisation and, more generally, to distinct regional policy. The argument made by scholars in this field is that regionalist parties are more likely to flesh out aspects of citizenship as a strategy to distinguish their claims from those of political competitors.

The issues surrounding the connection between citizenship rights and the government of regions are important because they raise a set of questions and possibilities about the co-existence of political communities. Theoretically, it is possible to imagine that uneven access to rights across the territory of a state, including for instance gay marriage, voting, and health care, can result from the action of the governments of regions that do not claim further autonomy or full independence from the federal state they belong to. This is not only a relevant theoretical puzzle; it is also an important empirical question, as regions that do not have special autonomy represent 93 percent of the population within Western European and North American countries (Hooghe et al., 2016).

This article aims to fill this gap in the literature by focusing on the drivers that explain why and on the mechanisms that show how regional governments include or exclude undocumented immigrants into health care rights. To this purpose, the article tests two hypotheses that build on the literature that untangles the rise of the regional level of government in several fields of public policy explaining it as part of a broader transformation of the nation-state. 
The first hypothesis is descriptive, and it postulates that the establishment of representative and accountable government at the level of the region provides new institutional resources for political leaders to adapt, blur, and ultimately re-define the meaning of citizenship for vulnerable subjects. This hypothesis is historically informed. Since the 1970s, economic, social and political systems that were previously part of rigidly defined hierarchical structures migrated to new levels of government (Brenner, 2009). Rescaling was often driven by functional change organised on a variety of different territorial levels, a phenomenon known as the 'new regionalism' (Keating, 1998). The outcome was not that of single territorial grids; instead, rescaling led to the construction of a multiplicity of spaces of transformation and governance, strengthening both supra- and subnational institutions. On the one hand, supra-national institutions like the European Union (EU) established new territorial boundaries. On the other hand, the progressive institutionalisation of specific policies at the sub-national level led to a process of gradual 'region-building' (Ferrera, 2003; McEwen and Moreno, 2005; Keating, 2013; Greer, 2016). Rescaling creates the favourable conditions for the politics of regional citizenship to emerge: the creation and empowerment of new levels of government brings greater incentives for the action of those institutions that are situated outside the national setting of the state.

At the same time, and this is the second hypothesis of the article, the literature on territorial rescaling suggests that devolved territories, faced with the need to boost investment and lacking control over macro-economic powers, are led to cut social standards. The political economy literature from Charles Tiebout (1956) onwards has built on the assumption that the mobility of capital and citizens across the borders of subnational units leads governments to achieve an equilibrium between levels of taxation and public expenditure that reflects the interests of capital and a mobile citizenry. This leads to horizontal competition and a multiplication of veto points that undermine cooperation, empower special interest groups, and make it harder to achieve improvements in social provisions. Public choice economists, in particular, describe decentralisation as a process wherein states seek to offload the cost of social welfare to regions and 
localities, and these in turn will cut their social standards in order to attract and retain footloose investors (Ohmae, 1995; Lovering, 1999). As a consequence of these processes, scholars working on political institutions fear that when the nation-state loses its essential role in the organisation of rights, no other tier of government can effectively perform that role (Bartolini, 2005; Obinger, Leibfried and Castles, 2005). This argument has also been used by politicians: for instance, the Canadian left opposed both the North American Free Trade Agreement and proposals to further decentralise the federation fearing a weakening of national solidarity. In short: the outcome of territorial rescaling is generally held to result in a race to the bottom in terms of social expenditure, as jurisdictions do their best to avoid becoming welfare magnets for the poor. This reading of territorial rescaling suggests, and this is the second hypothesis of the article, that the super-imposed processes of territorial rescaling trump the political agency of regional governments, which are left with no option but to lower the social standards within their territories.

The effects of this race to the bottom are likely to be particularly strong on vulnerable populations. There is evidence that decentralised polities have certain incentives to get rid of populations that are considered to be undesirable. In Switzerland, for instance, cantons historically insisted that social policy for internal migrants should be the responsibility of the canton of origin (Centlivres, 1990); in the Commonwealth, as a consequences of liberal 'laissez-faire' economic policies pursued by the British state, Irish immigrants were long disadvantaged (Zolberg, 2007); in the multilevel EU polity, states struggle to avoid Roma (and other Travelling peoples) in their territory (see Sardelic, 2019); and in the US, several states attempted to offload the costs of homeless people by sending them to California (Maas, 2016). These policies are likely to target vulnerable groups that, owing to their precarious membership status, have no electoral voice and cannot defend themselves through the ballot; their interests do not count for much in the democratic political process.

\section{Research design}


This article explains how the territorial rescaling of state affects rights that were traditionally used to define the boundaries of national citizenship by focusing on one domain of rights (health care), one group of vulnerable individuals (undocumented immigrants), and two pairs of regions in two multilevel countries (Lombardy and Tuscany in Italy, and Vaud and Zurich in Switzerland). While specific in its empirical focus, this comparison is part of a broader effort to explain how regional governments in multilevel states shape citizenship status and related rights.

\section{Object of observation}

There are two main reasons why I focus on social rights, and on the right to health care in particular. The first reason is that social rights carry specific costs that are related to the moral commitment of sharing with the others that is required for them to function. In contrast with civil liberties and political participation, the purpose of social rights is that of explicitly promoting reciprocity, mutuality and community. Social rights, in other words, serve as the glue that holds a diverse and democratic society together (Kymlicka and Banting, 2006; Mcewen, 2005). For Thomas H. Marshall (1950), full membership in the national community was based on the basic human equality that is entailed by social rights.

The second reason is that social rights directly affect the life chances of individuals. Providing basic poor relief or public care for HIV, cancer, and other diseases might even secure the survival of an individual, something that voting and having the freedom to speak cannot do. Health, in particular, is an important issue in its own right because it touches every aspect of human experience from birth to death. Until the nineteenth century, health care was detached from the status of citizenship: the Poor Laws in the UK, for instance, treated the claims of the vulnerable as an alternative to the rights of citizens (Marshall, 1950). Indeed, protection was provided mainly by private organisations, like charities, guilds, and religious institutions. The right to health care was taken under the umbrella of state citizenship with the progressive expansion of welfare and with the general expansion of the economies of post-war industrial societies, when it was assumed that 
citizenship should include the task of improving the life conditions of the members of the polity. ${ }^{1}$ Today, emergency treatment is a human right recognised by a number of international conventions. Yet, the idea of a universal human right to health care is at odds with the notion of citizenship, which presupposes a bounded community of recipients. In fact, the provision of services that go beyond emergency treatment remains linked to the idea of membership in the polity: by including certain populations and excluding others, governments signal who has a claim to be treated as an equal member. These are the reasons why the right to health care, perhaps more than other rights, reveals deep tensions revolving around norms of inclusion at different territorial levels of public authority.

The subjects of my study are referred to as 'undocumented immigrants'. Undocumented migration has become a fact of life in all EU countries resulting from the twin effect of continuous inflows and increasingly restrictive immigration policies (Triandafyllidou, 2016). The most recent calculation of the number of undocumented immigrants in Europe was provided by the European Commission's funded 'Clandestino Project: Counting the Uncountable: Data and Trends Across Europe' (2009), which estimated that between 1.9 and 3.8 million undocumented immigrants lived in Europe in 2008. These figures should be updated in the light of the most recent developments, with thousands of asylum seekers travelling to Europe from less developed parts of the world in the last few years. In most cases, undocumented immigrants are forced to take low-paid jobs, which leads them to live in overcrowded apartments, to eat unhealthy foods, and to experience a constant sense of precariousness. Yet, apart from the work of Sarah Spencer (2017), the rapid worsening of health that many undocumented immigrants experience is usually studied only from the perspective of public health or health policy rather than from a broader interest in citizenship and immigration politics.

\footnotetext{
1 Today, national health services have been established in several European countries, including Italy, Spain, and the UK; and in countries with health insurance systems, such as Belgium, Germany, Switzerland, coverage was progressively extended to become nearly universal. Public health care is still treated as residual and relies on strongly privatised provision in places like the US and Brazil.
} 


\section{Case selection}

I compare Italy and Switzerland because they lie at the extreme of a continuum of territorially multilevel states, the former being generally regarded as a rapidly regionalising country (Fabbrini and Brunazzo, 2003; Palermo and Wilson, 2014), the latter a well-established federal country (Kriesi and Trechsel, 2007). This comparison aims to test whether in non-federal countries like Italy, regions redefine citizenship; and whether the race to the bottom in the provision of social rights of citizenship occurs in both new regional states that are more directly affected by processes of territorial rescaling and old federations where the authority of the subnational units is historically entrenched.

In both countries undocumented immigration is an important phenomenon, but the national frameworks for dealing with it are very different. While Italy is a country of recent immigration (Sciortino and Colombo, 2004; Zincone, 2006), the history of immigration to Switzerland dates back to the beginning of the $20^{\text {th }}$ century (Ruedin, Alberti and D'Amato, 2015). Although imprecise, the figures available and reproduced in Appendix 5 show that undocumented immigrants in both countries represent a significant portion of the population. In Italy, for instance, the latest available report estimates the number of undocumented immigrants at around 349,000, which, in relative terms, represents less than one percent of the resident population (Cuadra, 2010). In Switzerland, a recent study set the number of undocumented immigrants in the country at roughly 76,000, or slightly less than one percent of the resident population (Morlok et al., 2015).

Importantly for the comparison, these two countries have decentralised health regimes with a tradition of universal health care. The Italian Sistema Sanitario Nazionale (SSN) and the Swiss system agglomerate public health services whose management is effectively transferred to the regions and the cantons, respectively. Yet, there are important differences in how health care is organised in these countries. The Italian SSN is financed through taxation and is considered to be an example of 'the Southern model of welfare' (Ferrara, 1996) due to the way in which it combines 
universalism with high levels of economic informality. This is different from Switzerland, where health care is based on a private insurance system whose regulation is the responsibility of the state (Immergut, 1992). Still, the cantons have several ways in which they can affect the organisation of health care. For example, they can decide to financially subsidise those individuals whose basic resources are not enough to pay the cost of social insurance; and they can supplement the lack of insurance by creating alternative access channels that function without requiring health care insurance (Bilger et al., 2011). The Swiss Constitution protects the right to be helped and to receive the essential resources for a dignified human existence to all individuals in a situation of distress. ${ }^{2}$ Documented and undocumented immigrants have traditionally enjoyed the right to emergency health care without insurance coverage, while for all other health services that are not considered urgent they must be insured: by virtue of the 1996 Federal Law on Health Insurance or 'Loi fédérale sur l'assurance-maladie', public insurance companies have to accept all persons irrespective of their legal and health status. In practice, however, few undocumented immigrants are able to get health insurance due to its high cost (Wyssmüller and Efionayi-Mäder, 2011, p. 22). The Italian Constitution provides a more inclusionary framework aimed at the elimination of any obstacle to the enjoyment of the right to health. ${ }^{3}$ The issue of undocumented immigrants was addressed for the first time with Legislative Decree no. 286 of July 1998, which mandates that undocumented immigrants should be guaranteed specific services like pregnancy care, the protection of minors, prophylaxis, and vaccinations. In a series of subsequent decisions, the Italian government introduced additional specifications to the type of intervention that should be guaranteed, so that the

\footnotetext{
${ }^{2}$ Article 12 reads: 'Persons in need and unable to provide for themselves have the right to assistance and care, and to the financial means required for a decent standard of living'. Furthermore, Article $41 \mathrm{~b}$ requires the federal government and the cantons to ensure that everyone has access to the health care that they need: 'The Confederation and the Cantons shall, as a complement to personal responsibility and private initiative, endeavour to ensure that ... every person has access to the health care that they require'.

${ }^{3}$ Article 32 states that the Republic protects health as a fundamental right of the individual and a collective interest. The Article reads as follows: 'The Republic safeguards health as a fundamental right of the individual and as a collective interest and guarantees free medical care to the indigent. No one may be obliged to undergo any health treatment except under the provisions of the law. The law may not under any circumstances violate the limits imposed by respect for the human person'.
} 
range of health care rights was both clarified and broadened. According to the current legislation, undocumented immigrants are not entitled to register in the SSN, but they can access health care via the temporary residing foreigner code. A basic level of cross-regional harmonisation was established in December 2012, with the signature of an agreement by the State-Regions Conference, which adopted the guidelines set by the Health Commission of the Conference of Regions and Autonomous Provinces. The agreement established shared standards for the correct application of the legislation on health care rights for immigrants, both documented and undocumented. As a result of these norms, Italy has one of the most favourable normative frameworks concerning health care for undocumented immigrants in the European Union (Cuadra, 2012; Marceca, Geraci and Baglio, 2012; PICUM, 2013, p. 13; Huddleston et al., 2015). Ultimately, the two countries represent, respectively, a regionalised state with rather generous health care legislation at the national level in the case of Italy and a federal state with rather restrictive health care legislation at the national level in the case of Switzerland.

For each country I chose two subnational governments: those of Lombardy and Tuscany in Italy, and those of Vaud and Zürich in Switzerland. The selection has been restricted to cases that are most similar in many respects. In terms of control of fiscal revenues, for instance, all the cases selected have some room for manoeuvre; and in terms of financial resources, these are relatively well-off territories with a high coverage of health services (Wyss and Lorenz, 2000; Costa Font, 2010). All regions selected are also similar in the sense that they are characterised by the presence of important urban centres (Lausanne in Vaud, Zürich in Zürich, Florence in Tuscany, and Milan in Lombardy) and by a large share of immigrants and undocumented immigrants (see Appendix 5). In terms of representation, all the cases selected are governed by directly elected institutions. ${ }^{4}$ At the same time, the regions selected have been governed by either left or right-wing governments for a

\footnotetext{
${ }^{4}$ In Switzerland, the cantonal parliaments of Vaud (Grand Conseil) and Zürich (Kantonsrat) are elected every four years, together with the cantonal collegial executives of seven persons, which are also directly elected in a popular vote. In Italy, the regional assemblies (consigli regionali) of the regions of Lombardy and Tuscany are elected every five years and, since 1999, so are also the regional presidents.
} 
period of over ten years. In Italy, Tuscany has been governed by the Partito Comunista Italiano (PCI) and then the Partito Democratico (PD), both left wing parties, since the first regional election in 1970. By contrast, Lombardy has been governed by right wing parties, notably Forza Italia (FI) and the Lega Nord (LN) since 1995. In Switzerland, where partisan politics are arguably harder to establish, Vaud has historically been one of the cantons where coalitions of left-wing parties have been strongest in contrast with Zürich, where the right-wing Schweizerische Volkspartei (SVP) has had a relative majority of seats since the late 1990s. More specific information on the composition of the regional and cantonal governments over time are provided in Appendix 4. Indeed, the regions selected are not necessarily representative of the whole of the variation within a country. However, the comparison should allow us to explain whether and why subnational governments produce meaningful forms of membership.

\section{Data}

I use two different sources of information to address the subject of this article: (1) legal texts that concern, either directly or indirectly, the right to health care for undocumented immigrants; and (2) a set of semi-structured interviews with a broad variety of key informants. In the first part of my research I relied mainly on information concerning the decisions and the actions of regional governments, rather than on official declarations, parliamentary debates, and party manifestos. To this purpose, I first did desktop research of the relevant legal and administrative texts at the national and regional level. The documents I have collected refer, either directly or indirectly, to the regulation of health care for undocumented immigrants. In the end, I analysed 19 legal documents, including national and regional legislation as well as directives and regulations. A full list of the documents analysed is detailed in Appendix 1.

Contestation of citizenship does not stop with the establishment of rules: sometimes, informal practices are very different from what we would expect by looking exclusively at how formal norms are defined in constitutions, legislation, and in the jurisprudence. In order to control 
for correct interpretation of the law, trace its genealogy, and its realisation in practice, as well as the motivations of the actors, I conducted 40 semi-structured interviews. The population of interest for my interviews were elite actors who are particularly influential in the processes observed. My informants had been directly involved in the processes analysed - public officials, doctors, nurses, and members of NGOs - or had privileged knowledge about them for their work - researchers, professors. A first set of interviewees was identified through secondary literature attempting to give equal representation to the different groups of professionals. A second set of interviewees was added through snowballing, that is by using the small pool of initial contacts to nominate, through their social networks, other respondents who meet the eligibility criteria. This strategy of selecting interviews is therefore based on a combination of purposive sampling with subsequent snowball selection. A full list of the interviewees is detailed in Appendix 2, while the template of questions I usually asked is reproduced in Appendix 3.

\section{Steering the wheel of rights: how and why regional governments shape citizenship}

The comparison reveals that national rules governing health care and, more generally, citizenship rights in multilevel systems should not be understood as if they were applied homogeneously across the territory of the state. In Italy, the government of Tuscany has encouraged assistance to undocumented immigrants in public hospitals; by contrast, the authorities of Lombardy have restricted the access of undocumented immigrants to health care by limiting their registration to the emergency care service of public hospitals. In Switzerland, the government of Vaud has integrated undocumented immigrants in public hospitals, while the government of Zürich has left their assistance to the discretionary care of private actors and NGOs. This evidence suggests that regional governments maintain different approaches to what citizenship entails and for whom.

\section{Between eligibility and access: the toolkit of regional governments shaping citizenship}

There are several ways in which regional governments can shape rights that were traditionally used 
to define the boundaries of national citizenship. Regional variations can be obscured by a narrow focus on legislation: such variation happens, and matters, also through procedural requirements, organisation of the service, and strategies of communication with the public. In general, regional governments can affect both eligibility, i.e. the definition of who has the right to public health care, and access, i.e. the possibility to benefit from this right in practice.

Regional governments can expand eligibility to the right of health care in two ways. First, regional governments can pass legislation that modifies, either directly or indirectly, the definition of those who are beneficiaries of certain rights. The example here is law 29/2009 of the region of Tuscany, which promotes and supports the right to health 'of foreign citizens as a fundamental right of the person'. By using such a broadly encompassing definition, the region includes all immigrants regardless of their status. Regional governments can also affect the provision of rights by means of administrative provisions. An example of such administrative adjustment is the package of rules passed by the government of Vaud in 1957, establishing dedicated services in the public university hospitals to provide care to everyone living in the canton. Since 2002 this task has been performed by the Unité des Populations Vulnérables and the Centre de Santé Infirmier at the university hospital of Lausanne, which recognises NGOs as complementary actors in this process. Traditionally, the main users of this service were homeless people and, later in the twentieth century, immigrants; today, nearly all users are undocumented immigrants and asylum seekers.

At the same time, regions can restrict eligibility by remaining silent on the necessary implementing measures that are often required to bring vulnerable individuals into the system. In Italy, for instance, the national legislation sets some minimum standards to be followed, but the lack of implementing measures from the regional government of Lombardy leaves the right to health for undocumented immigrants limited to emergency services. Lombardy is one of the eight Italian regions that have not ratified the agreement with minimum standards of protection agreed at the State-Regions Conference in 2012. Here, the task of assisting undocumented immigrants has been delegated to civil society organisations, which exist independently from the regional institutions and 
today continue to provide a substitutive rather than complementary function.

Regional governments can also modify access to rights either helping undocumented immigrants to receive health care or effectively preventing them from doing so. In general terms, these measures depend upon registration procedures, funding, organisation of the services and communication. Governments can, for instance, enhance access also by supporting projects of NGOs that are dedicated to specific groups. In Vaud, cantonal funding is essential for the continuation of the projects of the association Point d'Eau, which was established in 1998 to provide hygienic and medical services to all those individuals who 'simply cannot afford a minimum condition that should be normal: to feel good in their body' (from the presentation leaflet of the association, 2018). The association was recognised by the cantonal government and today it relies on public subsidies to function. Other practical measures can make it easier to communicate with patients. The availability of interpreters through a dedicated line in the region of Tuscany is one example; the publication of brochures in several languages by the university hospital of Lausanne is another. Finally, the employment of social workers and cultural mediators to assist doctors when it is required is reported as an important condition in the provision of health care to undocumented immigrants in the public hospitals of Tuscany. However, regional governments can also inhibit access to health care by making the availability of these services more difficult through bureaucratic hurdles. In Lombardy and Zürich, for instance, the subjects I interviewed referred to the decision of mandating first reception in hospitals to administrative personnel who, unlike medical staff, are not bound to the duty of assisting a patient and sometimes ignore the rules that mandate minimum standards of assistance regardless of one's legal status in the country.

Table 1. Regional governments affecting eligibility and access to health care rights: overview of the cases

\begin{tabular}{|l|l|l|l|}
\hline Lombardy & Tuscany & Vaud & Zürich \\
\hline
\end{tabular}




\begin{tabular}{|c|c|c|c|c|c|}
\hline \multirow{2}{*}{$\begin{array}{l}\text { Eligibility } \\
\text { Are } \\
\text { undocumented } \\
\text { immigrants } \\
\text { recognised as } \\
\text { holders of the } \\
\text { right to health } \\
\text { in the regional } \\
\text { health } \\
\text { legislation? }\end{array}$} & $\begin{array}{l}\text { Entitlement } \\
\text { Are there } \\
\text { legislative } \\
\text { documents } \\
\text { regulating the right } \\
\text { to health for } \\
\text { undocumented } \\
\text { immigrants? }\end{array}$ & No & $\begin{array}{l}\text { Yes } \\
\text { Regional law } \\
\text { no. } 29 / 2009\end{array}$ & $\begin{array}{l}\text { Yes } \\
\text { Décret } \\
810.211\end{array}$ & No \\
\hline & $\begin{array}{l}\text { Scope of coverage } \\
\text { What is included in } \\
\text { the right to health? }\end{array}$ & $\begin{array}{l}\text { Conditional } \\
\text { Emergency } \\
\text { care, } \\
\text { continuous } \\
\text { care, essential } \\
\text { care, special } \\
\text { categories }\end{array}$ & $\begin{array}{l}\text { Conditional } \\
\text { Emergency } \\
\text { care, } \\
\text { continuous } \\
\text { care, essential } \\
\text { care, special } \\
\text { categories, } \\
\text { general } \\
\text { practitioner }\end{array}$ & $\begin{array}{l}\text { Conditional } \\
\text { Emergency } \\
\text { care, } \\
\text { continuous } \\
\text { care, essential } \\
\text { care }\end{array}$ & $\begin{array}{l}\text { Conditional } \\
\text { Emergency } \\
\text { care }\end{array}$ \\
\hline \multirow[t]{2}{*}{$\begin{array}{l}\text { Access } \\
\text { Do policies } \\
\text { assist } \\
\text { undocumented } \\
\text { immigrants in } \\
\text { accessing health } \\
\text { care? }\end{array}$} & $\begin{array}{l}\text { Registration mode } \\
\text { Are there } \\
\text { administrative } \\
\text { demands for } \\
\text { documents which } \\
\text { may be difficult for } \\
\text { immigrants to } \\
\text { produce - e.g. } \\
\text { identity documents; } \\
\text { proof of address } \\
\text { from local } \\
\text { authority records? }\end{array}$ & $\begin{array}{l}\text { Proof of low } \\
\text { income, } \\
\text { medical } \\
\text { certificate, } \\
\text { proof of local } \\
\text { registration }\end{array}$ & $\begin{array}{l}\text { Proof of low } \\
\text { income }\end{array}$ & $\begin{array}{l}\text { Proof of low } \\
\text { income }\end{array}$ & $\begin{array}{l}\text { Proof of low } \\
\text { income, } \\
\text { identity } \\
\text { documents }\end{array}$ \\
\hline & $\begin{array}{l}\text { Availability of } \\
\text { cultural and } \\
\text { language services } \\
\text { Is there provision } \\
\text { of cultural and } \\
\text { language } \\
\text { mediators? }\end{array}$ & Yes & Yes & Yes & No \\
\hline
\end{tabular}

These are examples of how regional governments add to, shape, and cut from the bundle of rights that are initially determined by the state. Aside from legislative barriers to entitlements, regional governments may also use subtle mechanisms in order to deliver or inhibit the delivery of rights. In this sense, the politics of regional citizenship is at times hardly visible. The table above illustrates how the governments of Lombardy and Zürich follow an approach of deliberate inaction on this issue, leaving the responsibility to assist undocumented immigrants to NGOs and civil 
society organisations. By contrast, the governments of Tuscany and Vaud provide for some forms of assistance, opening small doors for undocumented immigrants to access the full range of health care rights.

\section{Racing for rights: partisanship as the indispensable activating spark}

The evidence presented in the table above suggests that while territorial rescaling leads to some sort of race, this is not invariably going to the bottom. The argument is that while there are indeed multiple pathways to relatively weaker forms of protection for vulnerable individuals, there are also some back streets to more inclusive regimes. The findings concerning Tuscany and Vaud, in particular, point to the importance of conjunctions of political actors. In these regions, it was precisely when national governments were dominated by right-wing parties that regional and cantonal governments became sites of stronger social solidarity. The time when the legislation and the expansion of the rules of access to rights by the government of Vaud was most intense coincided with the late 1990s and early 2000s, when the right-wing anti-immigration Schweizerische Volkspartei (SVP) gained one additional seat within the Swiss Federal Council. Similarly, the regional government of Tuscany took a strong public stance defending some of the rights of undocumented immigrants - and legislated accordingly, see Appendix 1 - as a reaction to the anti-immigration policies pursued by the right-wing national government in the early 2000 s and then again between 2008 and 2009. Notably, the regional legislation was approved at a time when the electoral campaign for the Tuscan regional assembly was in full swing.

However, there is also evidence to show how some regional governments do indeed pursue a race to the bottom in the protection of rights for vulnerable subjects. The cases of Lombardy and Zürich are characterised by the silence of their right-wing governments, even in the presence of a national government passing legislation in this field. In 2016, opposition parties in Lombardy brought a motion to the regional assembly, demanding the government to collaborate with the NGOs in organising health care rights for undocumented immigrants. To this date, the government 
has not taken any actions towards that goal. One of the respondents I spoke to, a doctor evidently frustrated by the impossibility to find interlocutors within the regional government in Milan, told me that the problem 'is not that we cannot see the light at the end of tunnel; the problem is that there is no tunnel' (20 April 2017). In fact, within the governmental offices of Lombardy and Zürich there are no organisations that deal, explicitly or implicitly, with undocumented migration. This complicates matters not only for researchers who need to access the data, but also for left-wing national governments and for the NGOs that strive to protect the rights of vulnerable subjects.

These findings show that the partisanship of the respective subnational government is the indispensable activating spark that allows or inhibits actions concerning the right to health care for undocumented immigrants. Using strong majorities in the respective assemblies, regional and cantonal governments chart their own path towards the protection of vulnerable individuals. A lack of votes for left-leaning parties in Lombardy and Zürich has impeded upon greater protection of the rights of undocumented immigrants. In Tuscany and Vaud, by contrast, changes to the legislation took place shortly before the elections, showing that political agency and political dynamics define the content of policy in some very important ways. The different choices made by regional governments in the field of health care - but also, at least theoretically, in the field of electoral rights and social welfare at large - reflect the preferences of voters in nested demoi: both the national demos and the regional demos elect governments with some room of manoeuvre in the definition of rights and statuses.

However, while partisanship always drives the subnational contestation of citizenship, the decisions of regional governments might also be shaped by other factors: these include the relative electoral power of different parties, the context in which their struggles take place, the policymaking capacity of municipalities and their political majorities, and the way in which their policies are framed in the public sphere. The comparison here does not get into the details for each of these factors, but it points to the fact that representative and accountable government at the level of the region provides institutional resources that political leaders are inclined to use, just like the advent 
of the modern state fixed social and economic systems at the national level (Keating, 2016). In other words, my argument is that while partisanship does not entirely explain the subnational contestation of citizenship, it is a precondition to it. In this sense, the politics of regional citizenship holds insights for the broader literature, by providing evidence of how multilevel governance 'could well represent not a party-free zone, but rather another contentious arena where politics is carried out by different means other than rhetoric and ideology' (Campomori and Caponio 2017, italics in the original). The field of health care for undocumented immigrants, in particular, is illustrative of how regions are battlegrounds over contentious issues related to the attribution of rights, therefore shaping the scope of citizenship.

Until recently, insufficient knowledge about the ways in which and the reasons why regional governments shape rights has hampered our capacity to think of regional citizenship as a concept in its own right, alongside, nested within, and sometimes challenging national citizenship. The comparison of Italian regions and Swiss cantons shows that partisanship is a key driver in the contestation of rights that were traditionally used to define the boundaries of national citizenship in multilevel states. Regional citizenship is a second-order status that supervenes on national citizenship and cannot be understood separately from it. While national programmes are likely to remain the prime guarantor of rights in the future, the politics of regional citizenship adapt, blur, and ultimately re-define their meaning.

\section{Conclusion}

'Citizenship' and 'region' have seldom been studied together. When they have, research has usually focused either on federal states or on those regions and contexts where there is a secessionist threat engineered by parties mobilizing linguistic, ethnic, or cultural differences. My contribution adds to the existing literature in two ways. First, it shows that there is contestation of citizenship rights even if there is no federal arrangement and no regional party threatening secession: this is what I propose to define as the politics of regional citizenship. Second, it explains that regional party politics is the 
key driver of contestation of citizenship in a process that I term regional governments steering the wheel of rights. The general point of this article is that national rules determining citizenship rights in multilevel systems should not be understood as if they were applied coherently and homogeneously across the subnational units because the establishment of representative and accountable government at the level of the region provides new institutional resources for political leaders to adapt, blur, and re-define the meaning of citizenship for vulnerable subjects.

Regions in Italy and cantons in Switzerland have developed different approaches to what citizenship entails and for whom, therefore having at least some degree of influence over who is a deserving recipient of rights in the community. In practice, we have observed a wide variation across cases in the way in which they handle the rights of vulnerable subjects. Contrary to the initial expectation of this paper, territorial rescaling - i.e. structures - does not invariably lead to a race to the bottom in the provision of rights for vulnerable individuals. Instead, regional governments - i.e. political agency - regulate the rights of vulnerable populations following their political ideology. Even falling short of full sovereignty, regions shape their own spaces of citizenship by contesting some of those rights that constituted the hallmark of national citizenship for most of the twentieth century.

Indeed, the politics of regional citizenship is elusive. Regional governments do not always have the full armamentarium of citizenship that central national governments possess. Yet, they sometime pioneer, mitigate and resist the decisions of the central government, ultimately redefining the meaning of citizenship for vulnerable subjects. They do so in two ways: either through explicit legislative acts that allow them to redefine the conditions of eligibility, or through more subtle regulations that allow them to redefine the practical conditions of access to rights. In the course of these actions, regional governments within multilevel states maintain varied processes for working out an unravelling consensus around different ideas about who deserves to be a citizen and what rights she or he is entitled to. 


\section{Bibliography}

Arrighi, J.-T. (2012). Those Who Came and Those Who Left. The Territorial Politics of Migration in Scotland and Catalonia (Doctoral dissertation). San Domenico di Fiesole, Florence: European University Institute.

Arrighi, J.T. (2019, forthcoming). 'The people, year zero': Citizenship and the politics of independence in Scotland and Catalonia. Ethnopolitics.

Ayele, Zemelak A, and de Visser, J. (2017). The (Mis) Management of Ethno-Linguistic Diversity in Ethiopian Cities. Ethnopolitics, 16(3), 260-278.

Bartolini, S. (2005). Restructuring Europe: Centre Formation, System Building and Political Structuring between the Nation State and the European Union. Oxford, UK: Oxford University Press.

Béland, D. and Lecours, A. (2016). The 2014 Scottish Referendum and the Nationalism-Social Policy Nexus: A Comparative Perspective. Canadian Political Science Review, 10(1), 1-30.

Bilger, V. and Hollomey C. (2011). Health Care for Undocumented Migrants in Switzerland: Policies People - Practices. Vienna: Swiss Federal Office of Public Health and International Center for Migration Policy Development. Available at: https://www.bag.admin.ch/dam/bag/en/dokumente/natgesundheitsstrategien/nat-programm-migration-und-gesundheit/health-care-provisioneducation/Undocumented Migrants People.pdf.download.pdf/Undocumented Migrants People.pdf

Brenner, N. (2009). Open questions on state rescaling. Cambridge Journal of Regions, Economy and Society, 2(1), 123-139.

Brubaker, R. W. (1992). Citizenship and Nationhood in France and Germany. Cambridge, MA: Harvard University Press.

Campomori, F. and Caponio, T. (2017). Immigrant Integration Policymaking in Italy: Regional Policies in a Multi-level Governance Perspective. International Review of Administrative Sciences, 83(2), 303-321.

Centlivres, P. (1990). Devenir suisse. Adhésion et diversité culturelle en Suisse [Becoming Swiss. Membership and Cultural Diversity in Switzerland]. Geneva, Switzerland: Georg.

Clandestino Project (2009). Undocumented Migration: Counting the Uncountable. Data and Trends Across Europe, final report. Athens, Greece: Hellenic Foundation for European and Foreign Policy. Available at: http://clandestino.eliamep.gr/wp-content/uploads/2010/03/clandestino-final-report_november-2009.pdf

Costa-Font, J. (2010). Devolution, Diversity and Welfare Reform: Long-term Care in the 'Latin Rim'. Social Policy \& Administration, 44(4), 481-494.

Cuadra, C. B. (2010). Policies on health care for undocumented migrants in EU27: Italy. Malmö, Sweden: MIM/Health and Society Malmö University. Available at: http://files.nowhereland.info/662.pdf

Cuadra, C. B. (2012). Right of Access to Health Care for Undocumented Migrants in EU: a Comparative Study of National Policies. European Journal of Public Health, 22(2), 267-271.

Deshpande, R., Kailash, K. K. and Tillin, L. (2017). States as Laboratories: the Politics of Social Welfare Policies in India. India Review, 16(1), 85-105.

Fabbrini, S. and Brunazzo, M. (2003). Federalizing Italy: the Convergent Effects of Europeanization and Domestic Mobilization. Regional \& Federal Studies, 13(1), 100-120.

Ferrara, M. (1996). The 'Southern Model' of Welfare in Social Europe. Journal of European Social Policy, $6(1), 17-37$.

Ferrera, M. (2003). European Integration and National Social Citizenship: Changing Boundaries, New Structuring? Comparative Political Studies, 36(6), 611-652.

Ferrera, M. (2005). The Boundaries of Welfare. European Integration and the New Spatial Politics of Social 
Solidarity. Oxford, UK: Oxford University Press.

Greer, S. L. (2005) (Ed.). Territory, Democracy and Justice. Regionalism and Federalism in Western Democracies. Basingstoke, UK: Palgrave Macmillan.

Greer, S. L. (2016). Devolution and Health Policy in the UK. Health Policy, 14(4), 22-24.

Hepburn, E. (2011). "Citizens of the region": Party Conceptions of Regional Citizenship and Immigrant Integration. European Journal of Political Research, 50(4), 504-529.

Hooghe, L., Marks, G., Schakel, A. H., Chapman-Osterkatz, S., Niedzwiecki, S., and Shair-Rosenfield, S. (2016). Measuring Regional Authority: a Postfunctionalist Theory of Governance, Volume I. Oxford, UK: Oxford University Press.

Hooghe, L., Marks, G. and Schakel, A. H. (2010). The Rise of Regional Authority: a Comparative Study of 42 Democracies (1950-2006). New York, NY: Routledge.

Huddleston, T., Bilgili, Ö., Joki, A-L., and Vankov, Z. (2015). Migrant Integration Policy Index 2015. Barcelona and Brussels: CIDOB and MPG. Available at: http://mipex.eu/

Immergut, E. M. (1992). The Rules of the Game: the Logic of Health Policy-making in France, Switzerland, and Sweden. Structuring Politics: Historical Institutionalism in Comparative Analysis, 4(4), 57-89.

Jeram, S. (2013). Sub-state Nationalism and Immigration in Spain: Diversity and Identity in Catalonia and the Basque Country. Ethnopolitics, 13(3), 225-244.

Jeram, S., van der Zwet, A. and Wisthaler, V. (2015). Friends or foes? Migrants and sub-state nationalists in Europe. Journal of Ethnic and Migration Studies, 42(8), 1229-1241.

Joppke, C. (2010). Citizenship and immigration. Cambridge, UK: Polity.

Keating, M. (1998). The New Regionalism in Western Europe. Territorial Restructuring and Political Change. Cheltenham, UK: Edward Elgar Publishing.

Keating, M. (2013). Rescaling the European State: the Making of Territory and the Rise of the Meso. Oxford, UK and New York, NY: Oxford University Press.

Kriesi, H. and Trechsel, A. (2007). The Politics of Switzerland. Continuity and Change in a Consensus Democracy. Cambridge, UK: Cambridge University Press.

Kymlicka, W. and Banting, K. (2006). Immigration, Multiculturalism, and the Welfare State. Ethics \& International Affairs, 20(3), 281-304.

Lovering, J. (1999). Theory Led by Policy: the Inadequacies of the 'New Regionalism' (Illustrated from the Case of Wales). International Journal of Urban and Regional Research, 23(2), 379-395.

Maas, W. (2013). Varieties of Multilevel Citizenship. In W. Maas (Ed.) Multilevel Citizenship (pp.1-23). Philadelphia, PN: University of Pennsylvania Press.

Maas, W. (2016). European Governance of Citizenship and Nationality, Journal of Contemporary European Research, 12(1), 532-551.

Marceca, M., Geraci, S. and Baglio, G. (2012). Immigrants' Health Protection: Political, Institutional and Social Perspectives at International and Italian Levels. Italian Journal of Public Health, 9(3), 1-11.

Marshall, T. H. (1950). Citizenship and Social Class, and Other Essays. Cambridge, UK: Cambridge University Press.

Mcewen, N. (2005). The Territorial Politics of Social Policy Development in Multi-level States. Regional \& Federal Studies, 15(4), 537-554.

McEwen, N. and Moreno, L. (Eds.) (2005). The Territorial Politics of Welfare. Oxford, UK and New York, NY: Routledge. 
Morlok, M., Oswald, A., Meier, H., Efionayi-Mäder, D., Ruedin, D., Bader, D., and Wanner, P. (2015). Les sans-papiers en Suisse en 2015. [The sans-papiers in Switzerland in 2015]. Basel, Switzerland: PUB.

Obinger, H., Leibfried, S. and Castles, F. G. (2005). Introduction: Federalism and the Welfare State. In H. Obinger, S. Leibfried, and F. G. Castles (Eds.) Federalism and the Welfare State: New World and European Experiences (1-64). Cambridge, UK: Cambridge University Press.

Ohmae, K. (1995). The End of the Nation State: the Rise of Regional Economies. New York, NY: Free Press.

Palermo, F. and Wilson, A. (2014). The Multi-level Dynamics of State Decentralization in Italy.

Comparative European Politics, 12(4-5), 510-530.

PICUM (2013). Guaranteeing Access to Health Care for Undocumented Migrants in Europe: What Role Can Local and Regional Authorities Play? Platform for International Cooperation on Undocumented Migrants. Available at: http://picum.org/picum.org/uploads/publication/CoR Report Access to Healthcare EN_FR_IT_ES 2013.pdf

Ruedin, D., Alberti, C. and D'Amato, G. (2015). Immigration and Integration Policy in Switzerland, 1848 to 2014. Swiss Political Science Review, 21(1), 5-22.

Sardelic, J. (2019, forthcoming). Roma in the Times of Territorial Rescaling: An Inquiry into the Margins of European Citizenship, Ethnopolitics.

Schapiro, R. A. (2009). Polyphonic Federalism: Towards the Protection of Fundamental Rights. Chicago, IL and London, UK: Chicago University Press.

Schönberger, C. (2007). European Citizenship as Federal Citizenship: Some Citizenship Lessons of Comparative Federalism. European Review of Public Law, 61(19), 61-81.

Sciortino, G. and Colombo, A. (2004). The Flows and the Flood: the Public Discourse on Immigration in Italy, 1969-2001. Journal of Modern Italian Studies, 9(1), 94-113.

Spencer, S. (2017). Multi-level Governance of an Intractable Policy Problem: Migrants with Irregular Status in Europe. Journal of Ethnic and Migration Studies, 44(12), 2034-2052.

Tiebout, C. (1956). A Pure Theory of Local Expenditures. Journal of Political Economy, 64(5), 416-424.

Triandafyllidou, A. (2016). Irregular Migration in Europe: Myths and Realities. London, UK and New York, NY: Routledge.

Wyss, K. and Lorenz, N. (2000). Decentralization and Central and Regional Coordination of Health Services: the Case of Switzerland. International Journal of Health Planning Management, 15, 103-114.

Wyssmüller, C. and Efionayi-Mäder, D. (2011). Undocumented Migrants: their Needs and Strategies for Accessing Health Care in Switzerland. Neuchâtel, Switzerland: Swiss Forum of Migration.

Zincone, G. (2006). The Making of Policies: Immigration and Immigrants in Italy. Journal of Ethnic and Migration Studies, 32(3), 347-375.

Zolberg, A. (2007). The Exit Revolution. In N.L. Green and F. Weil (Eds.). Citizenship and Those Who Leave: the Politics of Emigration and Expatriation (33-60). Champagne, IL: University of Illinois Press. 